\title{
The Management of Heavy Equipment Retribution on the Increasing of Original Local Government Revenue in Ministry of Public Works and Public Housing of Aceh Jaya Regency
}

\author{
Irmayasa $^{1}$, Ismail ${ }^{2}$ \\ ${ }^{1,2}$ Universitas Iskandar Muda, Indonesia \\ irmayasa96@gmail.com
}

\begin{abstract}
The purpose of this research is to find out and analyze the management of heavy equipment levies to increase original local government revenue of Ministry of Public Works and Public Housing Aceh Jaya Regency. And also To find out and analyze the management of heavy equipment rental services in original local government revenue of Ministry of Public Works and Public Housing Aceh Jaya Regency. The conclusion of the research shows that the management of heavy equipment levies on the increase in original local government revenue of Ministry of Public Works and Public Housing Aceh Jaya Regency both related to the planning, regulation and supervision of heavy equipment has not been going well. While the financing aspect shows that the large operational budget needed for heavy equipment maintenance causes and puts a burden on the region, because the budget comes from the Aceh Jaya Regency APBk. Whereas the original local government revenue of Ministry of Public Works and Public Housing Aceh Jaya Regency deposit is always below the target set, the heavy equipment solid has a great potential for increasing original local government revenue of Ministry of Public Works and Public Housing Aceh Jaya Regency. Management of heavy equipment rental services related to service procedures, service commitments and time of rental. In connection with the procedure of renting services, it can run well because in the service procedure for renting heavy equipment rental activities, it must fill out the form provided and attach an identity in the form of a Identity Card and then ferment it. This is going well and in accordance with the rules that have been determined so that it can run well. Likewise with the commitment to leasing heavy equipment has been agreed between parties both personal leasing and rental for groups. Likewise with the time of rental daily and also monthly is not a problem, but many do rent on a monthly basis.
\end{abstract}

Keywords

retributionmanagement; heavy

equipment; original local

government revenue

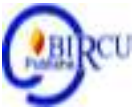

\section{Introduction}

Original local government revenue is a source of regional revenue originating from several regional revenue results and one of them is obtained from regional retribution revenue. The results of local user fees need to be endeavored to become a potential income for original local government revenue. The revenue from the regional levies sector is expected to be able to support regional funding sources in carrying out regional development, so that it will increase and level the economy and the welfare of the people in their regions. 
Konfrontasi Journal: Culture, Economy and Social Changes, 7 (2) June 2020, 147-157

ISSN: 1410-881X (Print), 2716-2095 (Online)

Irmayasa, Ismail: The Management of Heavy Equipment Retribution on the Increasing of Original Local Government Revenue in Ministry of Public Works and Public Housing of Aceh Jaya Regency DOI: https://doi.org/10.33258/konfrontasi2.v7i2.108

http://www.konfrontasi.net/index.php/konfrontasi2

One of the efforts to increase PAD can be done by increasing limited resources and facilities and increasing collection, namely by optimizing existing potentials and continuing to explore new sources of revenue that have potential, so that tax or retribution can be collected according to existing provisions. Regional levies which are payments for services or special licenses provided or given by local governments to individuals / entities, are expected to support regional funding sources in the implementation of regional development, so that it will improve and evenly distribute the economy and welfare of the people in their respective regions and especially in Aceh Jaya Regency.

Several factors that cause the regional retribution sector to be potential as a source of regional finance include:

1. Levies can increase Regional Original Revenue (PAD) in terms of financing government operations and regional development. Regional levies are levied on fees so that payments can be made repeatedly.

2. The collection of levies can be done outside the time determined by the legislative officer as long as the local government can provide services with the approval of the central government.

3. The levy sector is closely related to the level of socioeconomic activity of the community in an area.

Aceh Jaya is one of the regencies where there are still many problems in receiving heavy equipment levies that have not been managed optimally. Regional levies, in addition to being one of the sources of revenue for regional governments, are also the dominant factors in their role and their contribution to supporting local governments, one of which is heavy equipment levies. Heavy equipment levies as a source of original local government revenuesourced from heavy equipment tenants / the people who rent them, where the management is carried out by the Ministry of Public Works and Public Housing Aceh Jaya Regency.

One object of public service levies managed by the Ministry of Public Works and Public Housing Aceh Jaya Regency is heavy equipment fees. The data on the revenue realization of heavy equipment levies in Aceh Jaya Regency in 2016-2018 is as shown in table 1 below.

Table 1. Target of Receiving Heavy Equipment Retribution in 2016-2018

\begin{tabular}{|c|c|c|c|c|c|}
\hline No & Year & Target & Realization & Percentage & Information \\
\hline 1 & 2016 & $1.250 .000 .000,00$ & $578.700 .000,00$ & $46,30 \%$ & Not achieved \\
\hline 2 & 2017 & $590.000 .000,00$ & $362.900 .000,00$ & $61,51 \%$ & Not achieved \\
\hline 3 & 2018 & $810.000 .000,00$ & $301.000 .000,00$ & $37,16 \%$ & Not achieved \\
\hline
\end{tabular}

Source: Aceh Jaya District Public Works and Public Housing Agency

As for other problems in the Ministry of Public Works and Public Housing Aceh Jaya Regency, there are still problems regarding the physical conditions of the heavy equipment itself, therefore there is a need for immediate handling from the government. The current heavy equipment conditions for example; tool quality, lifetime, and tool performance. Given these problems the tenant will cancel to rent or enter into a cooperation contract in the use of the tool. Thus, the condition of the tool really needs to be considered because it is the tool that can provide user fees to increase local revenue. As explained earlier, one of the sources of Original Regional income is heavy equipment levies. Thus the need for attention from all parties, both elements of the government and society as mandatory levies in addressing how 
to manage existing heavy equipment levies so that they can truly contribute to the increase in Original Regional income.

From the explanation above, of course the management of the heavy equipment owned is always directed so that the owner of the heavy equipment can obtain the maximum possible production at the optimum cost. However, the fact of the matter is that the condition of the tool that is not so optimal in use, in other words, the performance of the tool is no longer perfect because it requires maintenance to be used while retribution is unstable because to carry out maintenance of the tool costs a lot. Based on these conditions, it can be seen that the current condition of heavy equipment is very worrying due to lack of maintenance. Such conditions certainly require special attention from the Regional Government, not to mention the suboptimal service from the levies collectors.

\section{Review of Literature}

\subsection{Management Theory}

Management as a process carried out to achieve goals by working together. Talking about management means talking about management functions such as planning. Planning or what is known as planning is one of the very important management functions. Even planning activities are always attached to daily activities. A plan will greatly affect the success and failure of a job. Therefore good work begins with a plan. According to Siagian (2015) planning is "The process that contains activities in the form of thinking, calculation, selection, determination all of which are carried out in order to achieve certain goals". Whereas Sebastian in Siagian (2015) defines planning as "The process of making decisions on a number of alternatives (choices) regarding targets and ways to be implemented in the future in order to achieve the desired goals and their monitoring and evaluation of the results of their implementation, carried out systematically and continuously ".

According to Terry in Siagian (2015) management is "A process of planning, organizing, leadership, and controlling the efforts of members of the organization and the use of resources available in the organization to achieve a goal set by the organization before". Jones Siagian (2015) stated that management is "The process of planning, organizing, leading and controlling human resources and others to achieve organizational goals efficiently and effectively".

According to Randy (2017) management basically has various functions including:

a. Planning (Planning). Planning is the process of setting organizational goals. Planning requires the ability to project what future events will look like so that steps or choices can be made in this process.

b. Organizing (Organizing). Organizing in an organization by reviewing plans that have been made and determine what activities will be carried out.

c. Staffing (Staff Recruitment). After going through planning and organizing, the next step is to look for workers. In the process of finding workers, a manager must determine the expertise of the prospective worker.

d. Directing. The manager must lead the workers and provide motivation so that the goals of the organization are achieved. The manager must tell him what needs to be done and make the right deadlines so that the task can be completed on time.

e. Controlling (controlling). After all the above activities are carried out, the manager must evaluate all activities that have been running in the organization, whether it is in line with the objectives to be achieved or even deviated far. Control is done to avoid organizational failure by giving a review every month. 


\subsection{Public Service Theory}

Public service delivery is an attempt by the state to fulfill the basic needs and civil rights of every citizen of goods, services and administrative services or services in the form of providing various forms of documents required by the public. According to Gieovani in Tjiptono (2014) which defines service is "service for the community or activities of the organization carried out to practice and devote to the organization carried out to practice and devote themselves to the community".

Providing services or serving the needs of people or the community and / or other organizations that have an interest in the organization, in accordance with the basic rules and procedures determined and intended to provide satisfaction to the recipient of the service. The process of activities in a service is not only determined by one party, but from all parties involved in the service. Four important elements in the process of public service according to Hardiyansyah (2014), namely:

a. Service providers are parties who can provide a particular service to consumers, both in the form of services in the form of supply and delivery of goods or services.

b. Service recipients are those referred to as consumers (customers) or customers who receive various services from service providers.

c. Types of services are services that can be provided by service providers to those who need services.

d. Customer satisfaction, in providing services, service providers must refer to the main purpose of service, namely customer satisfaction.

Based on several theories above that explain about public services. So, in order for the explanation to be more complete and in depth, the writer adds a description of the Aceh Qanun Number 8 of 2008 concerning Public Services. Article 2 and 3 paragraph 1 and 2 include:

a. The delivery of public services is carried out in accordance with the general principles of good government administration.

b. General principles of good governance as referred to in paragraph (1) include:

- Islam;

- justice;

- humanity;

- orderly administration of government;

- legal certainty;

- proportionality;

- equality;

- openness;

- participatory;

- accountability;

- public interest;

- professionality;

- equal rights;

- balance of rights and obligations;

- efficiency;

- effectiveness;

- continuous; and

- gender sensitivity 


\subsection{Concepts of Financial Management}

Management is a term used in management science in terms of etymology of management derived from the word "manage" (to manage) and usually refers to the process of taking care or handling something to achieve goals. Manage comes from the word "manage" which can be interpreted in the form of doing, managing and organizing activities or better known as management. Management is the same as management principles relating to 4 aspects of management, namely planning, organizing, implementing and monitoring as well as utilizing resources including human resources to achieve an organization's goals.

Management will be achieved if the steps in the implementation of management are applied appropriately, the steps of implementing the management based on the objectives according to Walgito (2015) are as follows:

- Determine the strategy

- Determine the means and limits of responsibility.

- Determine targets that include yield criteria, quality and Time constraints.

- Determine the operation of tasks and plans.

- Determine work standards that include effectiveness and efficiency.

- Determine the size to judge.

- Carry out an assessment.

- Conduct periodic review.

- Implementation of the next stage, takes place repeatedly.

\subsection{Concept of Original Local Government Revenue}

Original local government revenue is revenue that is obtained from regional revenue sources and is managed by the regional government itself. Regional Original Revenues are the backbone of regional payments, therefore the ability to implement the economy is measured by the amount of contribution provided by Regional Original Revenues to the Regional Government Budget, meaning that the dependence of regional governments on central government assistance is smaller. Based on Law Number 28 of 2009 concerning Fiscal Balance of the Central Government and Regional Governments, Regional Original Revenues consist of "Regional taxes, regional levies including proceeds from the services of the Local Community Service Agency, management of separated regional assets, etc. legitimate local revenue ".

The contribution of Original local government revenue to regional income depends on the contribution of its components, namely regional taxes, regional levies, the results of the management of separated regional wealth, etc. The legitimate of Original local government revenue can be seen through the contribution to Original local government revenue. The role of each component of Original local government revenue influences the contribution of Original local government revenue to income. And the amount of revenue realization reflects the success of the government in collecting revenue.

\section{Research Method}

In this study, researchers used a descriptive qualitative approach to describe the management of heavy equipment levies to increase local real income at Ministry of Public Works and Public Housing Aceh Jaya Regency. In this case the researcher wants to gain an understanding in accordance with the research objectives stated in the previous chapter, then in this study using qualitative research methods. Through a qualitative approach, a deep understanding and thought about the meaning, reality, and relevant facts regarding the 
increase of original local government revenue of Ministry of Public Works and Public Housing Aceh Jaya Regency.

According to Usman (2015: 4) research using descriptive methods intends to "make a standardization systematically, factual, and accurate about the facts and the characteristics of certain populations". In other words this research aims to describe the nature of something that is taking place at the time of study. While Nawawi (2015: 63) also expresses in a different language but the same meaning about descriptive methods that is to say descriptive methods can be interpreted as "Problem-solving procedures investigated by describing / the state of subjects / objects of research (a person, institution, community) at the present time based on facts that appear or as is ".

This research was conducted at original local government revenue of Ministry of Public Works and Public Housing Aceh Jaya Regency, Aceh Province, having its address at Jalan Mahkota Number 14, tel (0651) 22106340. Fax. (0654) 2210079 with postal code 23654, Calang Aceh Jaya. The choice of office is due to Ministry of Public Works and Public Housing Aceh Jaya Regency as an institution that manages heavy equipment levies. The determination of the informants was done by purposive sampling and data collection through observation and interviews. While the data analysis is done through data reduction, data presentation and verification for drawing conclusions.

\section{Discussion}

This research was conducted in Aceh Jaya Regency, precisely at the office of the Public Works and Public Housing Office of Aceh Jaya Regency. The results of the study relating to the management of heavy equipment levies mainly related to planning showed that the results of interviews with several informants showed that planning in the management of heavy equipment levies had been carried out, but not yet effectively, so the results were not in accordance with the previously set targets. Therefore, the arrangement of heavy equipment needs to be reviewed so that its management has a positive impact on increasing the original income of the Aceh Jaya Regency.

Arrangement of heavy equipment is very necessary, this is also done by the Government of Aceh Jaya Regency to increase revenue from heavy equipment retribution which has not been managed optimally. Regional levies, in addition to being one of the sources of revenue for regional governments, are also the dominant factors in their role and their contribution to supporting local governments, one of which is heavy equipment levies. Heavy equipment levies as a source of original local government revenue sourced from heavy equipment tenants / the people who rent them, where the management is carried out by Ministry of Public Works and Public Housing Aceh Jaya Regency. Based on researchers' interviews with the Head of Ministry of Public Works and Public Housing Aceh Jaya Regency on Monday, May 11, 2020, said that "The arrangement of heavy equipment is very necessary so that the heavy equipment is maintained until old age and to reduce maintenance costs, but in its implementation there are very many obstacles".

The arrangement of heavy equipment is one of the tasks of Ministry of Public Works and Public Housing Aceh Jaya Regency, so that the equipment that perform operations will be thinned. Arrangements made in the public interest in conducting services need interrelated relationships that also arise because of obligations as a process of carrying out the activities of government organizations. Based on the interview of researchers with the Head of Subdivision of the equipment of Ministry of Public Works and Public Housing Aceh Jaya Regencyon Tuesday, May 12, 2020, said that "The arrangement of heavy equipment is 
carried out so that it is efficient in use, bearing in mind the number of heavy equipment owned by the Government of Aceh Jaya Regency is very limited".

The arrangement of heavy equipment is part of carrying out public service tasks, because the provision of public services can be carried out by the government or by private parties on behalf of the government for the needs of individuals or communities who have an interest in the organization, in accordance with the basic rules and procedures determined and intended to provide satisfaction with service recipients. Based on the interview of the researcher with the Treasurer, the reception of the Public Works Office of Aceh Jaya on Wednesday, May 13, 2020, stated that "The arrangement of heavy equipment certainly has to do with the receipt of original local government revenue, but so far we realize that the regulation of heavy equipment has not gone well".

Based on interviews conducted by researchers with several informants, conclusions can be drawn that the arrangement of heavy equipment at Ministry of Public Works and Public Housing Aceh Jaya Regency has not been going well, because the arrangement is still not going according to the provisions of the Regional Government.

In managing heavy equipment retribution, in addition to planning and regulation, supervision of heavy equipment is also needed. This is very necessary to ensure that the heavy equipment operates in accordance with the duration and location of the agreement between the worker and the Regional Government of Aceh Jaya Regency as the owner of the heavy equipment. Supervision is one of the management functions that are indispensable in carrying out various activities both organizations and also private activities. Therefore, based on the interview of researchers with the Head of Ministry of Public Works and Public Housing Aceh Jaya Regency on Monday, May 11, 2020, said that "We have been regulating heavy equipment in such a way, of course in accordance with applicable regulations, but in practice there are still many that deviate, meaning the heavy equipment operator or renter does not carry out in accordance with an agreement that has been mutually agreed ".

The implementation of supervision in an organization aims to assess the performance of an institution or an organization, in this case of course the Ministry of Public Works and Public Housing Aceh Jaya Regency. Therefore, in every activity of an organization it is absolutely necessary to supervise, even the routine existence of a monitoring system. Thus supervision is a control instrument that is inherent in every operational stage. The oversight function can be carried out at any time, both during the management or administrative process and after it ends to find out the level of achievement of an organization's or work goals. Based on researcher interviews with the Head of Ministry of Public Works and Public Housing Aceh Jaya Regency program program on Monday, May 11, 2020, said that:

Supervision carried out by Ministry of Public Works and Public Housing Aceh Jaya Regencyhas not been maximized, because it is still found that the implementation is not on time and not on target. For example, in the agreement, the heavy equipment operates 100 hours, but the reality in the field when supervision is over, as well as the location of the work. This is detrimental to the Regional Government because it is related to the amount of original local government revenue and it is still ongoing even though supervision has been carried out.

Based on interviews with several informants it can be concluded that the supervision conducted by the Government of Aceh Jaya Regency for the supervision of heavy equipment has not had a positive impact on increasing original local government revenue.

While the results of the research relating to the financing aspect which consists of operational costs indicate that the operational budget is allocated annually as a heavy equipment maintenance cost which is asep for the Aceh Jaya Regency Government. The operational budget is sourced from the District Budget or known from the APBK ". 
The operational budget in managing levies needs to be done in a transparent and accountable manner in providing services. Therefore, services must be carried out transparently and accountably by each service unit because the quality of public services has broad implications in achieving the welfare of the community. Based on researchers' interviews with the Head of Ministry of Public Works and Public Housing Aceh Jaya Regency program on Monday, May 11, 2020, said that "The allocation of heavy equipment operational budgets has been done transparently and openly, so that all people who need information can be obtained easily".

Management so that operational is related to all available resources such as human resources, equipment, or facilities that exist in an organization can be moved in such a way as to avoid wasting all time, energy and material in order to achieve the desired goals, management is needed in all organizations, because without the management or management all efforts will be in vain and the achievement of goals will be more difficult. Management will be achieved if the steps in the implementation of management are implemented appropriately, the steps of implementing the management are based on the objectives

Based on the interview of researchers with the Head of Subdivision of the equipment of Ministry of Public Works and Public Housing Aceh Jaya Regency on Tuesday, May 12, 2020, said that "We are transparent to the operational budget of the heavy equipment from the first proposal to the stage of detailing the use of money in rupiah terms, meaning that it is transparent and makes sense when we compile in a report that can be seen by the public ".

The implementation of regional autonomy that is real, dynamic, harmonious, and responsible, of course the region must be able to provide the necessary funds that come from sources of financing owned, mainly from original local government revenue sources. Based on the interview of the researcher with the Treasurer, the reception of the Ministry of Public Works and Public Housing Aceh Jaya Regency on Wednesday, May 13, 2020 stated that "We do transparency in every operational management of heavy equipment, because all budgets issued from APBK sources will be audited by the National Audit Board".

From interviews conducted by researchers with several informants, conclusions can be drawn that the Public Works Department of Aceh Jaya always puts forward an attitude of transparency in the management of heavy equipment operations, but the contribution of retribution is still very limited.

The low heavy equipment levies cause at least the original local government revenue obtained from heavy equipment leasing, so the heavy equipment levies management has not gone well. This is in accordance with the results of the researchers' interview with the Head of Ministry of Public Works and Public Housing Aceh Jaya Regency program on Monday, May 11, 2020, which said that "We have made various efforts to increase the retribution of heavy equipment rentals, but the reality has always not reached the target. The low heavy equipment retribution is also caused by the heavy equipment being often damaged and many already old".

The results of the researchers' interview with one of the informants from the Head of Ministry of Public Works and Public Housing Aceh Jaya Regency on Tuesday, May 12, 2020 said that "Seteron heavy equipment levies became cash for the Aceh Jaya District. The levy is one source of original local government revenue which has been used as part of the Aceh Jaya APBK. The size of the retribution is very dependent on the amount of levies obtained ". Thus the results of the study showed that the retribution obtained by the Government of Aceh Jaya Regency was classified as small in number and did not meet the target year after year.

Furthermore, the potential of original local government revenue from renting heavy equipment shows that the potential of original local government revenue from heavy equipment is very large, but the condition of heavy equipment that is no longer good has an impact on the low retribution received, so that the financial aspects incurred for the 
maintenance of heavy equipment is very large and naturally can reduce original local government revenue. And the amount of original local government revenue received from year to year does not always meet expectations.

In connection with the technical aspects, the results of the study show that the number of heavy equipment varies from one model to another, so the cost of restoration is also different. The types of heavy equipment possessed by Ministry of Public Works and Public Housing Aceh Jaya Regency are numerous and some are rarely used so they still require maintenance costs. Furthermore related to the condition of heavy equipment as interviewed by researchers with the Head of Ministry of Public Works and Public Housing Aceh Jaya Regency on Monday, May 11, 2020, said that the kurwa "The condition of heavy equipment is now mostly less productive, so that even though there is income for original local government revenue there are also many maintenance costs so that it becomes a dilemma of its own."

The same thing but with different languages was also conveyed by other informants. Based on researchers' interviews with the Head of Ministry of Public Works and Public Housing Aceh Jaya Regency program on Monday, May 11, 2020, said that "The condition of old heavy equipment and the amount of maintenance costs, especially for heavy equipment that is often used by itself can drain the APBD".

The condition of material processing equipment, although rarely used, requires depreciation costs. The machine only functions to convert natural rocks and minerals into a desired shape and size. Material produced from the process of this tool in the form of graded rock, cement, concrete, and asphalt. Which includes the types of heavy equipment are crusher and concrete mixer truck. Based on the interview of researchers with the Head of Subdivision of the equipment of Ministry of Public Works and Public Housing Aceh Jaya Regency on Tuesday, May 12, 2020, said that "We will re-evaluate heavy equipment according to the conditions, because some are not productive anymore and some of them are rarely used".

The current condition of heavy equipment is very worrying due to lack of maintenance. Such conditions certainly require special attention from the Regional Government, not to mention the suboptimal service from the levies collectors. Meanwhile, based on researchers' interviews with the Treasurer, the reception of the Public Works Office of Aceh Jaya on Wednesday, May 13, 2020 stated that "The limited source of Regional Original Revenue original local government from heavy equipment and on the other hand the need for maintenance costs to be a dilemma for the heavy equipment itself".

Based on interviews with several informants, it can show the results that the condition of heavy equipment is old and many are no longer productive, but still require large maintenance costs, this cannot add to original local government of Aceh Jaya Regency. Thus, the technical aspects of managing heavy equipment levies have not had a positive impact on increasing original local government.

While relating to the management of heavy equipment rental services shows that each individual or group that rents heavy equipment at Ministry of Public Works and Public Housing Aceh Jaya Regency is obliged to fill in the form provided because it is an absolute requirement in the procedure for heavy equipment rental services. Heavy equipment rental is carried out for the personal benefit of each member of the community. Based on researchers' interviews with the Head of Ministry of Public Works and Public Housing Aceh Jaya Regencyon Monday, May 11, 2020, stated that "Many heavy equipment is leased for business or project work done by individuals, but for us what is important is its commitment in paying off rental fees as a source of original local government revenue for Aceh Jaya Regency ".

Then based on the interview of the researcher with the Head of Ministry of Public Works and Public Housing Aceh Jaya Regency on Monday, May 11, 2020, said that "Many private individuals make heavy equipment rental transactions and that is permitted in the 
rules of origin where the commitment is clear". A similar informant was conveyed by another informant during a research interview with the Head of Subdivision of Ministry of Public Works and Public Housing Aceh Jaya Regency on Tuesday, May 12, 2020, said that "There are individuals who rent heavy equipment for personal interests such as hoarding and opening a $\mathrm{C}$ excavation business, and $\mathrm{C}$ excavation $\mathrm{C}$ it must have separate permits from this machine".

Then based on the interview of the researcher with the Treasurer, the reception of Ministry of Public Works and Public Housing Aceh Jaya Regencyon Wednesday, May 13, 2020 stated that "personal leasing is more when compared to rentals carried out by groups". Based on interviews with several informants that the management of heavy equipment rental services at Ministry of Public Works and Public Housing Aceh Jaya Regencywas carried out in a procedural manner and maintained commitment in service.

Rental of heavy equipment at Ministry of Public Works and Public Housing Aceh Jaya Regency in addition to personal interests is also for the benefit of groups. Based on the interview of the researcher with the Head of Ministry of Public Works and Public Housing Aceh Jaya Regency on Monday, May 11, 2020, said that "For us, for personal interests and for the interests of the groups the same, what we see is commitment to leasing from the parties, because the results are to increase original local government revenue of Ministry of Public Works and Public Housing Aceh Jaya Regency".

Then based on researcher interviews with the Head of Aceh Jaya District Public Works Department program program on Monday, May 11, 2020 stated that "The commitment of leasing is a reference for us in carrying out heavy equipment rental activities both for individuals and for certain groups in doing their various businesses".

The same information was also conveyed by a different informant during a researcher interview with the Head of Ministry of Public Works and Public Housing Aceh Jaya Regency equipment on Tuesday, May 12, 2020, saying that "it is important for us not to rent heavy equipment, but to commit to the rental we need to carry out and obey together ".

Then, based on the interview of the researcher with the Treasurer, the reception at Ministry of Public Works and Public Housing Aceh Jaya Regencyon Wednesday, May 13, 2020 stated that "The commitment of leasing for personal and group interests is the same and the treatment is the same, therefore we do not question the need but only identify it."

Based on interviews with several informants, conclusions can be drawn on the indicator that "Heavy equipment rental is carried out due to the interests of community groups". The results showed that both individuals and groups had the same commitment in leasing heavy equipment at Ministry of Public Works and Public Housing Aceh Jaya Regency.

Based on the results of the study it can be formulated various findings including the following:

Finding 1:

The planning and arrangement of heavy equipment at Ministry of Public Works and Public Housing Aceh Jaya Regency has not been going well, even though the management aspects of heavy equipment levies have become an expectation for an increase in original local government revenue.

Finding 2:

Financing aspects incurred for the maintenance of heavy equipment is very large so that by itself it can reduce original local government revenue. And the amount of original local government revenue received from year to year always does not meet the target.

Finding 3:

Technical aspects in the management of heavy equipment levies have not had a positive impact on increasing original local government revenue. 
Finding 4:

Completion of forms and personal and group identities is an absolute requirement in the heavy equipment rental service procedure.

Finding 5:

Both individuals and groups have the same commitment in leasing heavy equipment at the Public Works Office of Aceh Jaya Regency

Finding 6:

The rental time for heavy equipment within the Aceh Jaya District Public Works Department is daily and adapula on a monthly basis, but more is leased on a monthly basis.

\section{Conclusion}

Management of heavy equipment levies to increase original local government revenuein the Department of Ministry of Public Works and Public Housing Aceh Jaya Regency, both related to the planning, regulation and supervision of heavy equipment has not been going well. While the financing aspect shows that the large operational budget needed in the maintenance of heavy equipment causes and puts a burden on the region, because the budget is sourced from the Aceh Jaya Regency Regional Government Budget. Whereas the original local government revenue deposit is always below the target set, the heavy equipment solid has a great potential for increasing original local government revenue.

Management of heavy equipment rental services related to service procedures, service commitments and rental times. In connection with the procedure of renting services, it can run well because in the service procedure for renting heavy equipment rental activities, it must fill out the form provided and attach an identity in the form of a Identity Card and then ferment it. This is going well and in accordance with the rules that have been determined so that it can run well. Likewise with the commitment to leasing heavy equipment has been agreed between parties both personal leasing and rental for groups. Likewise with the time of rental daily and also monthly is not a problem, but many do rent on a monthly basis.

\section{References}

Hardiyansyah. (2014). Kualitas Pelayanan Publik Konsep,Dimensi, Indikator dan Implementasinya. Yogyakarta: Gava Media.

Nawawi, H. (2007). Metode Penelitian Bidang Sosial. Gajah Mada University Press: Yogyakarta.

Randy, R. W. dan Riant Nugroho. (2017). Manajemen Pemberdayaan. Jakarta: PT Elex Media Komputindo.

Siagian, Sondang P. (2015). Fungsi-Fungsi Manajerial. Jakarta: Bumi Aksara.

Tjiptono, Fandy. (2014). Strategi Pemasaran.Yogyakarta: Andi.

Usman Husaini, Akbar Purnomo Setiady. (2009). Metodologi Penelitian Sosial. Jakarta: PT Bumi Aksara.

Walgito, Bimo. (2015). Pengantar Administrasi Umum. Yokyakarta: CV. Andi.

Qanun Aceh Nomor 8 Tahun 2008 tentang Pelayanan Publik.

Undang-Undang Republik Indonesia Nomor 28 Tahun 2009 Tentang Pajak Daerah dan Retribusi Daerah. 